\title{
A Method of Data Treatment for X-Ray Stress Measurement
}

by

\author{
Yasuo YoshioKA \\ (Musashi Institute of Technology, Tokyo)
}

The standard method for X-ray stress measurement was recently established by the Committee on Mechanical Behaviour of Material, Japan. Thus, the stress determination by means of $\mathrm{X}$-rays will be more widely used in the future at laboratories or factories on the basis of this standard, and the automatic measurement will be required as the numbers of measurement increase.

In "the standard method", the diffraction profile is recorded as the intensity-angle curve by means of a counter. The peak position of the profile, $2 \theta$, is graphically determined by the halfvalue breadth method, and the stress $\sigma$ is then calculated from the gradient of $2 \theta-\sin ^{2} \psi$ diagram.

In this paper presented is a half-value breadth method by digital computation to determine the peak position of profile, which is suitable for the automatic measurement of X-ray stress. Several examples are also shown. In this method, the diffraction intensities are converted to the digital values at equal intervals in the diffraction angle. The background line of profile is calculated from the data of both ends of the profile on the basis of correlation coefficient of linear regression. The half-value breadth line is then drawn parallel to the background line. The values at the intersections between the half-value breadth line and the profile are calculated approximately by the simultaneous equations, and the midpoint between two intersections is defined as the peak position.

The measurements of stress were performed by the standard method and this computation method on several carbon steel specimens. The measured values of peak position of profiles by these two methods almost agreed each other, and the difference of stresses by these methods was as small as under $1 \mathrm{~kg} / \mathrm{mm}^{2}$.

(Received Aug. 30, 1973)

\section{1 緒}

X線応力測定法は，この十年程の間に飛躍的な進歩 を遂げ，特に残留応力の測定に関しては最も一般的な 測定法として取り扱われるよらになった。そらして， 最近ではX線応力測定標準も制定され，その用途がさ らに增大することが予想される。

このような現状で，さらに望まれることの一つは， 測定を自動化して省力化を図るとともに，測定誤差を 少なくすることである。自動化の試みは，すでにある 程度は実行されているが，本格的な研究開発はこれか らといら段階である。

X線応力測定を自動化するにあたっては，i）試料

* 原稿受理 昭和 48 年 8 月30日

** 正会 員 武蔵工業大学 東京都世田谷区玉堤
の装置へのセット，ii）X線入射角, 計数管の走查範 囲の設定，運転などの測定プロさス，iii）データの集 録执よび処理の三段階に一応分けて，その扮の扮のに ついて自動化の方法を検討，さらにこの三つを有機的 に結合することが必要である。この場合，i）の試料 の装置へのセットに関しては，同一形状寸法の特定場 所の測定といらような場合を除いては，技術的深相当 困難であり，またその必要性もあまりないようである。 ii）の測定プロセスの自動化については，小型の電子 計算機と装置の結合により比較的容易に実現すること が可能であり，現に市販の装置にも取り付けられてい るものがある.

さて, iii）のデータ処理等に関しては, 結果に直接 影響を与兄るためきわめて重要であるが，現在その方 
式は定玉ったものが見当たらない，今まで，最も多く 用いられX線応力測定標準でも採用されている方法は, 自記記録した回折強度曲線のピーク位置を半価幅法で 求め, $\sin ^{2} \psi$ 法により応力を算出するものである。こ のプロセスが最も時間を要し, また, 誤差の入る確率 の多い部分である。このプロセスを電算機を導入して 自動化するためには，上述のようなアナログデータは 不適当であり，回折強度曲線を何らかの形でディシタ ル型のデータとして表わして処理することが望ましい． この種の処理を行なら場合，上く採用される方法は， 定時計数法で, 回折線ピーク付近の強度を三点あるい は五点測定して放物線近似を行ないピーク位置の算出 を行なら方法であった。しかしながら，X線応力測定 では, 測定する材料により回折線幅は狭いものから広 いものまでを取り扱わねばならず，その形状によって は放物線近似がしがたい場合や、バックグラウンドの 補正が必要になることがある。また，応力測定標準で 制定されている力法による測定值との対比もあまり検 討がされていない.そうして, 自動化して応力を測定 するにしても，できるだけ応力測定標隼に沿って行な うことが, データの互換性の点からも望ましい。

そこで, 本報告では, 回折強度を回折角 $2 \theta$ 上で等 間隔に記録して，ピーク位置を電算機を用いて半価幅 法で測定する方法を考光，自動データ集録装置をX線 応力測定装置に結合させ，集録したディジタルデータ より応力を求め, 測定標準による結果と比較㭘討した ところ好結果を得たのでその方法抢よび実測結果など を報告する。

な特，本報では，測定標準による応力測定法をアナ ログ法, 本報で報告するディジタルデータによる測定 法をディジタル法と以下呼ぶことにする。

\section{2 ディジタルデータによるピーク位置決定法}

Fig. 1 は，半価幅法によるピーク位置決定法を図式 に示したものである。まず(1)両端の回折線スソ部分よ りバックグラウンド $A$ を求める. (2)バックグラウンド に平行で回折線最高位置飞接する線 $B$ を引く. (3) $A$ と $B$ の $1 / 2$ の位置を通る線 $C$ を引き回折線との交点をそ

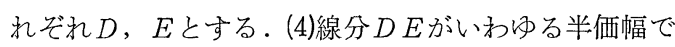

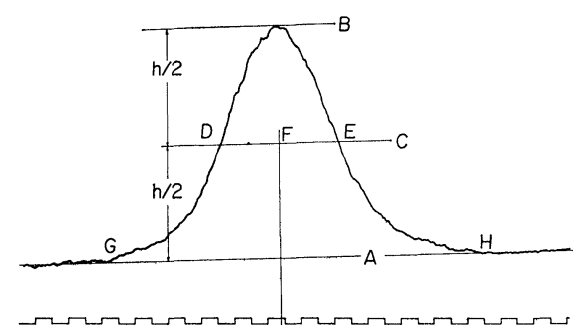

Fig. 1. Determination of peak position by halfvalue breadth method.

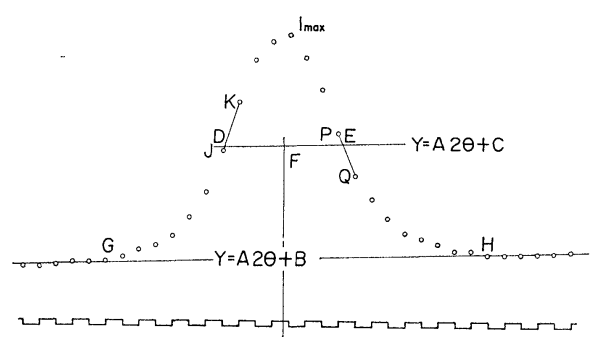

Fig. 2. Half-value breadth method by digital data.

あり，この中点 $F か ゙$ 求めるピーク位置である。これが X線灾力測定標準で採用されているピーク位置決定法 であり, 前述のように本報ではアナログ法と呼ぶ。

つぎに，この操作をディジタル計算によって行なう ことを考光る. 回折強度曲線の代わりに, Fig. 2 の上 万に，回折角上飞等間隔に回折強度 $I_{i}$ を測定する。 まず，Fig. 1のバックグラウンド線 $A$ の決定である. 通常のプロフィルは $\mathrm{K} \alpha$ 二重線, 吸収などのため非対 称であり，また装置の回折角 $2 \theta$ の走査範囲の制約な ぞから，低角側と高角側のバックグラウンドの長さが 等しくなるとは限らない。また, 応力測定ではプロフ ィル幅の狭いものから広いものまでを取り扱らため， あらかじめバックグラウンド長さを決めておくことも 困難である。そこで上記の諸条件を考虑して低角側よ り高角側への回折強度を $I_{1}, I_{2} \cdots \cdots I_{N-1}, I_{N}$ とした 際両端の三点ずつ，すなわち $I_{1}, I_{2}$ ‘ $I_{3}$ 牰よび $I_{N-2}$, $I_{N-1}, I_{N}$ の 6 個の值をもって仮のバックグラウンド 線

$$
y=A^{\prime} \cdot 2 \theta+B^{\prime}
$$

を求めた。ついで各回折角 $2 \theta_{2}$ に打沙る回折強度 $I_{2}$ と仮のバックグラウンド強度 $y_{2}$ の偏差自乗 $\left(I_{2}-y_{2}\right)^{2}$ を求め, この值の小さい順にデータ $\left(2 \theta_{2}, I_{2}\right)$ を並べ か壳，この順序にデータを 6 個とりバックグラウンド

$$
y=A \cdot 2 \theta+B
$$

および相関係数 $R$ を求めた。そうして，Rの值がある 設定值より小さくなるところまで，データ数を順次 1 個ずつ加光て， $A, B, R$ を再計算してバックグラウ ンドを決定する，Rの值は，図式にバックグラウンド を引いた際, 回折曲線が, この線より離れ始める点, すなわちFig. 1 の,$H$ 点より外側のデータが $A, B$ の決定にすべて使われるように設定すればよい，した がって実測によってあらかじめ決めて和く必要がある。 ついで, 回折強度の最大值 $I_{\max }$ 探し, (2)式より 半価幅線 $C$ を求める。 $I_{\max }$ に対応する回折角を，2 $\theta_{\max }$ とすれば，半価幅線の方程式は

$$
\begin{aligned}
y & =A \cdot 2 \theta+\frac{I_{\max }-A \cdot 2 \theta_{\max }+B}{2} \\
& =A \cdot 2 \theta+C
\end{aligned}
$$


となる。この半洒幅線がプロフィルと交わる点をそれ ぞれD，Eとするが，近似計算によって求めた。. Fig. 2 のプロットしたデータのらち, 低角側交点は $J$ そ の間に，高角側交点は $P$ と $Q$ の間に存在する。そこで， この 2 点間は直線とみなし, この直線と半価幅線 $C$ と の交点をD，Eとした。この 2 点の $2 \theta$ 座標をそれぞ れ $2 \theta_{D}$ と $2 \theta_{E}$ とするとピーク位置 $2 \theta_{F}$ は次式で与 えられる。

$$
2 \theta_{F}=\left(2 \theta_{D}+2 \theta_{E}\right) / 2
$$

データの読み込み抏よび以上のプロヒス, さらに $\sin ^{2} \psi$ 法による応力計算起行ならプログラム歨作成し て，ピーク位置物上び応力を求めた。この力法を本報 ではディジタル法と呼ぶ、実際にはX線応力測定装置 にディジタル型データ集録装置を取り付け，X線出才了 をテープアウトさせ，プログラムを実行させたので以 下との方法，結果について報告する。

\section{3 ディジ夕ルデー夕集録装置}

從来，X線強度分布をディジタルデータとして記録 する場合は，ステップスキャンニングによる定時計数 法或は，定計数時間測定法が採用されることが多い。 この方法は，X線強度のぼらつきによる䛊差が少なく， また，時定数をるたないため，正確な回折强度を求め るには適した方法で㐫るが，測定に要する時間が，一 般のアナログ的な自記記録法に刘してきるぬて多いの が欠点で岕る。

一方，X線応力測定を行ならとき，記録された回折 強度曲線を観察することにより，村料の状態たと兄 ば熱処理の適否, かたさ, 脱炭曆の有無, 結晶粒の大 小，異万性の有無なども㘯る程度判定することが可能 であり，応力值とともに，これらの観察絬果蛙材料強 度研究上重要な資料となる。しかし, 出力データがデ ィジタル型の場合は，上述のよらな材料状態を目視に よりただらに判定することは困難な場命が多い。そこ

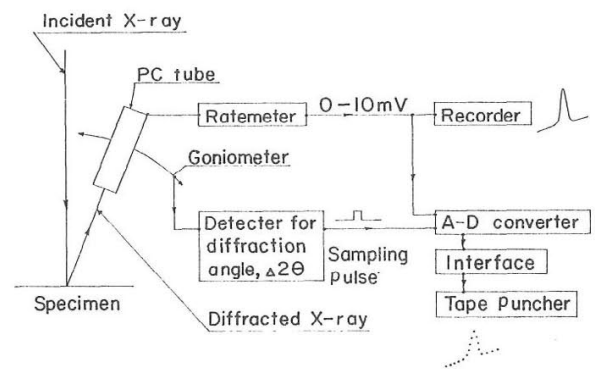

Fig. 3. Block diagram of equipment for X-ray stress measurement by digital computation.

*1 内部ひずみが少なく $\mathrm{K} \alpha$ 二重線がよく分颜する回折線について は，半洒幅線と回折線の交点が四点劣るいは三点となる可能性む あるが，応力测定では平行ビーム法芯朋い，またスリット発敞㑇 む大きいものを使用することにより内部ひずみの少ないるのです 明確な回折線の分刻がされがたく半洒幅線之二点 $D E$ のみで交わ ると仮定している.
で，従来の測定装置にディジタルデータ集録装置を装 着して,アナログ図形を従来ど和り記録させるととる に，等間隔ステップでX線强度をディジタル化させる 形式を採用した。Fig. 3 は，装置のブロック図である。 比例計数管よりのX線出力はレートメータを経て, 通 常ど打りレコーダへ送られる。一方, レートメータ出 力はアナログーディジ斥ル変換型電圧計へも送られ, ディジタル電压に変換される。甹うして，ゴニォメー タに取り付的られた回折角検出装置により, 回折角上 $0.1^{\circ}$ 間隔でサンプリング信号学 A-D変換器に送り, X線強度のサンプリングを行ない，テープへされ孔さ せた。サンプリング信号は、ゴニオメータ駆動軸がー 回転で 20 の $1^{\circ}$ に相当するので，Fig. 4のような円 板を駆動軸に外から取り付け，円周上に等分に10個の

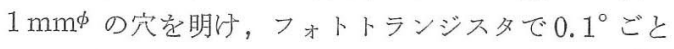
に回折角の検出空行なった、AーD变換器等の主な特 性を Table I に示す.

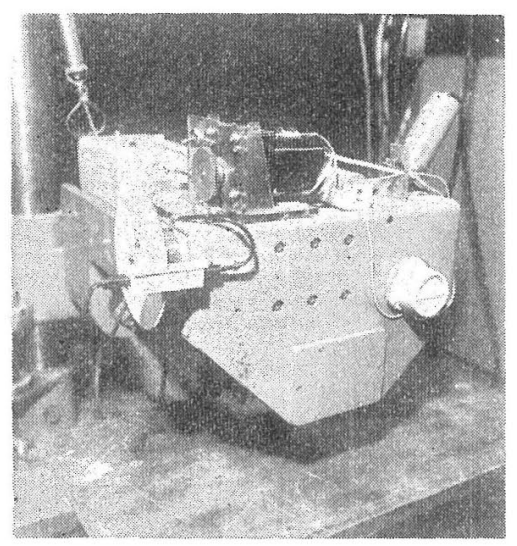

Fig. 4. Photoelectric detector for sampling of diffraction angle.

Table I. Specifications of A-D converter.

\begin{tabular}{ll}
$\Delta 2 \theta$ Detector & \\
\hline Detector & Phototransister \\
Count speed & $50 \mathrm{~ms}$ \\
Sampling interval & $0.1^{\circ}$
\end{tabular}

\section{A-D Converter}

$\begin{array}{ll}\text { Range } & 0-+9,999 \mathrm{mV} \\ \text { Number of figures } & \text { Four figures } \\ \text { Accuracy } & \pm 0.1 \%+1 \text { digit. } \\ \text { Resolving power } & 1 \mu \mathrm{V} \\ \text { Sampling speed } & 200 \mathrm{~ms}\end{array}$

\section{4 実 測 例}

まず，回折強度データの自動集録を行なうに先立っ て，自記記録した回折線プロフィル上で，回折強度を 
読み取りこれよりピーク位置, 応力を求めた。ついで, 試作した装置によりデータをA-D変換してテープア ウトしたものについて計算を行なった。

\section{$4 \cdot 1$ 使用材料および実測条件}

回折線プロフィルの幅の狭いものから広いものまで, 四種の炭素鋼試料をそろ光た。 Table II に材料の化 学組成, 熱処理, かたさ，半価幅を示す。

Table II. Chemical composition of materials and condition of heat treatment, hardness and half-value breadth of profile.

\begin{tabular}{|c|c|c|c|c|c|c|c|c|}
\hline Specimen & $\mathrm{C}$ & $\mathrm{S}_{1}$ & $\mathrm{Mn}$ & $\mathrm{P}$ & S & $\mathrm{Cu}$ & $\mathrm{Ni}$ & $\mathrm{Cr}$ \\
\hline$A, A^{\prime}, B$ & 0.33 & 0.22 & 0.70 & 0.017 & 0.008 & 0.13 & 0.05 & 0.07 \\
\hline$C, D$ & 059 & 1.78 & 086 & 0013 & 0.034 & 0.15 & 0.07 & 021 \\
\hline Specimen & \multicolumn{5}{|c|}{ Heat treatment } & \multicolumn{2}{|c|}{$H v$} & $\beta$ \\
\hline $\mathrm{A}, \mathrm{A}^{\prime}$ & \multicolumn{5}{|c|}{$900^{\circ} \mathrm{C}, 40 \mathrm{~min}, \mathrm{FC}$} & \multicolumn{2}{|c|}{180} & $1.6^{\circ}$ \\
\hline B & \multicolumn{2}{|c|}{$900^{\circ} \mathrm{C}, 20 \mathrm{~min}$, } & $\mathrm{OQ}, 3$ & $00^{\circ} \mathrm{C}$ & $1 \mathrm{hr}$. & \multicolumn{2}{|c|}{717} & $36^{\circ}$ \\
\hline $\mathrm{C}$ & \multicolumn{2}{|c|}{$850^{\circ} \mathrm{C}, 30 \mathrm{~min}}$, & $\mathrm{OQ}$ & $00^{\circ} \mathrm{C}, 2$ & $2 \mathrm{hr}, \mathrm{OQ}$ & \multicolumn{2}{|c|}{$324-327$} & $20^{\circ}$ \\
\hline $\mathrm{D}$ & \multicolumn{2}{|c|}{$850^{\circ} \mathrm{C}, 30 \mathrm{~min}$, } & $\mathrm{OQ}$ & $300^{\circ} \mathrm{C}$ & $2 \mathrm{hr}, \mathrm{OQ}$ & \multicolumn{2}{|c|}{$2|645-650|$} & $5.5^{\circ}$ \\
\hline
\end{tabular}

測定機器は平行ビーム式X線応力測定装置であり, Table III に示す条件にてプロフィルを描かせた。応 力測定はいずれも $\sin ^{2} \psi$ 法によったが，試料 $\mathrm{A}, \mathrm{A}^{\prime}$ および $\mathrm{B} は \psi$ 固定法 $\left(\theta-2 \theta\right.$ 法)，Cおよび $\mathrm{D}$ は $\psi_{0}$ 固 定法（X線入射角固定）を採用した. 回折強度の読取 間隔は，A， $A^{\prime}$ 拉よびCについては $0.2^{\circ}$ 打きに，B， Dについては $0.5^{\circ}$ 物きにして，自記させたプロフィ ルより強度を読み取った。

ついで, データ自動集録装置により回折強度を $0.1^{\circ}$ 扣きに記録したものについてピーク位置执よび応力を

Table III. Conditions for stress measurement by $\mathrm{X}$-rays. (Diffraction intensities were measured from profile recorded.)

\begin{tabular}{|c|c|c|c|c|c|}
\hline \multicolumn{3}{|c|}{ Characteristic X-ray } & \multicolumn{3}{|c|}{$\mathrm{V}$-filtered $\mathrm{Cr}-\mathrm{K} \alpha$} \\
\hline \multicolumn{3}{|c|}{ Diffraction plane } & \multicolumn{3}{|c|}{$\alpha-\mathrm{Fe}(211)$} \\
\hline \multicolumn{3}{|c|}{ Tube voltage } & \multicolumn{3}{|c|}{$30 \mathrm{kV}$} \\
\hline \multicolumn{3}{|c|}{ Tube current } & \multicolumn{3}{|c|}{$2-10 \mathrm{~mA}$} \\
\hline \multicolumn{3}{|c|}{ Irradiated area } & \multicolumn{3}{|c|}{$2 \times 10 \mathrm{~mm}^{2}$} \\
\hline \multicolumn{3}{|c|}{ Slit divergence } & \multicolumn{3}{|c|}{$0.70^{\circ}$} \\
\hline \multicolumn{3}{|c|}{ Scanning speed } & \multicolumn{3}{|c|}{$2^{\circ} / \mathrm{min}$} \\
\hline \multicolumn{3}{|c|}{ Chart paper speed } & \multicolumn{3}{|c|}{$40 \mathrm{~mm} / \mathrm{min}$} \\
\hline Specimen & Counter & $\begin{array}{l}\text { Count } \\
\text { range } \\
\text { (CPS) } \\
\end{array}$ & $\begin{array}{l}\text { Time } \\
\text { const } \\
\text { (SEC ) }\end{array}$ & $\begin{array}{l}\text { Scanning } \\
\text { range }\end{array}$ & $\begin{array}{l}\text { Sampling } \\
\text { interval }\end{array}$ \\
\hline$A, A^{\prime}$ & $\mathrm{PC}$ & 1000 & 8 & $148^{\circ}-164^{\circ}$ & $02^{\circ}$ \\
\hline B & $\mathrm{PC}$ & 1000 & 8 & $148^{\circ}-166^{\circ}$ & $05^{\circ}$ \\
\hline $\mathrm{C}$ & $\mathrm{S} \mathrm{C}$ & 4000 & 16 & $148^{\circ}-165^{\circ}$ & $02^{\circ}$ \\
\hline $\mathrm{D}$ & $\mathrm{S} \mathrm{C}$ & 2000 & 16 & $140^{\circ}-170^{\circ}$ & $05^{\circ}$ \\
\hline
\end{tabular}

Table IV. Conditions for stress measurement by $\mathrm{X}$-rays. (Diffraction intensities were converted to digital values from ratemeter out put voltage by the A-D converter.)

\begin{tabular}{ll}
\hline Characteristic X-ray & V-filtered $\mathrm{Cr}-\mathrm{K} \alpha$ \\
Diffraction plane & $\alpha-\mathrm{Fe}(211)$ \\
Tube voltage & $30 \mathrm{kV}$ \\
Tube current & $2-8 \mathrm{~mA}$ \\
Irradiated area & $2 \times 10 \mathrm{~mm}^{2}$ \\
Slit divergence & $070^{\circ}$ \\
Counter tube & $\mathrm{PC}$ tube \\
Count range & $1000 \mathrm{cps}$ \\
Time constant & $8 \mathrm{sec}$, \\
Scanning speed & $2^{\circ} / \mathrm{min}$. \\
Scanning range & $148^{\circ}-164^{\circ}$ \\
Chart paper speed & $40 \mathrm{~mm} / \mathrm{min}$. \\
Sampling interval & $01^{\circ}$ \\
Number of samples & 160 \\
\hline
\end{tabular}

測定した。X線装置は上述のものと同一で，主な測定 条件を Table IV に示す。ただ，回折線幅の最も広 い試料Dについては，装着したX線装置では測定がで きないので除外した。

\section{$4 \cdot 2$ 実測結果}

$4 \cdot 2 \cdot 1$ 回折プロフィルよりの測定結果 Fig. 5 に自記記録した回折プロフィルより強度を $0.5^{\circ}$ 扣き に測定，プロットした一例を示す．目測によりバック グラウンドを引き，回折線がバックグラウンドと離れ る点 $G, H$ を求めると, $G$ が $151^{\circ}, H$ が $162.5^{\circ}$ とな った。一方，仮のバックグラウンドを(1)式により求め, $\left(I_{2}-y_{2}\right)^{2}$ を計算, この值の小さい順に $I_{\imath}$ のデータを 並べ換光た結果が角度マーク上の数字である。注注低 角側と高角側飞等分に並び，Gは15，Hは14でありこ れより小さい番号のものは外側に存在する。そこでこ の番号 1 より15までのデータにより(2)式の計算を行な うと

$$
A=0.2098, B=-28.8254, R=0.9773
$$

となった。 Rの值は，バックグラウンドの凹凸，決定 に用いたデータ数に依存するが，凹凸を同一とすると データ数が多くなるほど，Rの值が小さくなる。した

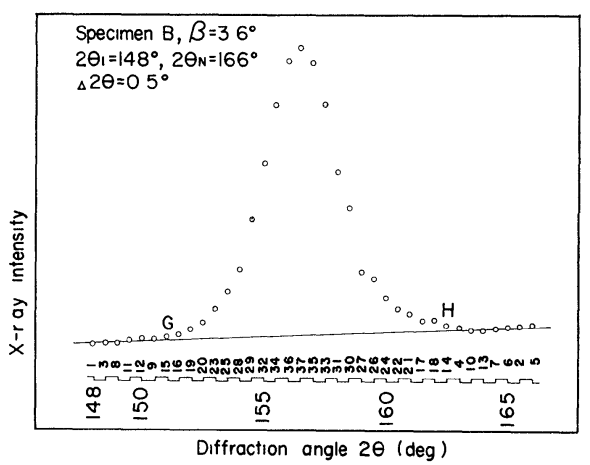

Fig. 5 Relation between diffraction intensities and diffraction angles 


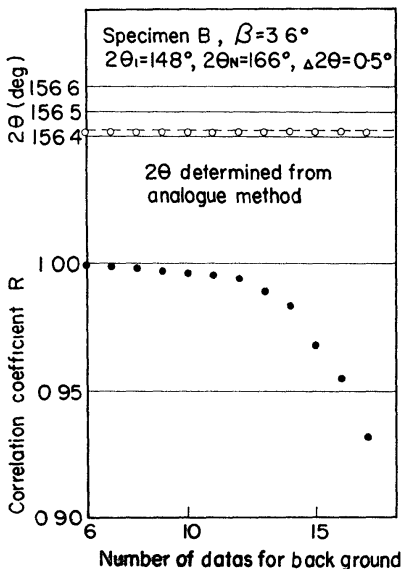

Fig 6. Change in peak position of profile with number of data for determination of background line.

がってサンプリングの間隔とバックグラウンド決定の データ数によりRの設定值を設ける必要がある。しか し，Fig. 6 に示すように，横軸にバックグラウンド決 定に用いたデータ数を，縦軸にピーク位置および相関 係数 $R$ の值をプロットすると，ピーク位置はデータ数 の大小にはあまり関係がない，通常の応力測定では， 回折角 $2 \theta$ の精度は小数点以下二桁をでで充分である ので，あまり，バックグラウンド決定のためのデータ 数を厳密に考光る必要はないようで，したがってRの 設定值についても沶拉よとの值で充分と考光る。

半価幅法によるピーク測定の特長は，バックグラウ ンドと回折線強度最大点の間の $1 / 2$ の高さに正確に半 価幅線がなくともピーク位置測定結果に与光る誤差が あまり大きくないことである、今回測定した回折線に ついても, 回折強度最大点とバックグラウンドの間の 高さの $\pm 5 \%$ 半価幅線を上下にずらしてもピーク位置 の変化は $0.005^{\circ}$ 程度までに扣さまった。したがって， バックグラウンド決定のデータ数の多少の差はピーク 位置決定には，沙とんど影響を与えないものと考光る。

ついで，ピーク位置扎よび応力值の測定結果を Table V に示す. 応力值について, アナログ法とデ ィジタル法の差は， $\mathrm{A}^{\prime} ， \mathrm{~B}$ を除いては $0.7 \mathrm{~kg} / \mathrm{mm}^{2}$ 以内になっている. $\mathrm{A}^{\prime}$ は $2 \theta-\sin ^{2} \psi$ 関係の直線性の 悪いものを選んだための結果であり，Bの場合は， が $18^{\circ}$ の場合のピーク位置が, アナログ法では $156.53^{\circ}$, ディジタル法では $156.497^{\circ}$ となっていることに起因 する。これは，Fig. 2 の $P Q$ 点の間が実際のプロフ ィルでは直線でなく, 少し高角度側へらくらんでいる ためにアナログ法によるピークが高角度側へあるため である、しかし，読取間隔を細かくすることによりこ の種の誤差は防ぎらるものと考觉られる。

以上のように, プロフィルから読み取ったデータに
Table $\mathrm{V}$ Values of peak position and stress.

\begin{tabular}{|c|c|c|c|c|c|c|}
\hline \multirow{2}{*}{$\frac{\text { Specimen }}{\Psi}$} & \multicolumn{2}{|l|}{ A } & \multicolumn{2}{|c|}{$\mathrm{A}^{\prime}$} & \multicolumn{2}{|l|}{ B } \\
\hline & $\mathrm{A}$ & $\mathrm{D}$ & A & $\mathrm{D}$ & A & $\mathrm{D}$ \\
\hline $8^{\circ}$ & 156.30 & 156.296 & 15620 & $156.207 \mid 1$ & 156.58 & 156574 \\
\hline $18^{\circ}$ & 156.28 & 156.266 & 156.22 & 156.186 & 15653 & $156 \quad 497$ \\
\hline $28^{\circ}$ & 15620 & 156.202 & 156.23 & 156.201 & 156.43 & 156.421 \\
\hline $36^{\circ}$ & 156.15 & 156.158 & 156.23 & 156.2091 & 156.35 & 156.345 \\
\hline $43^{\circ}$ & 156.10 & 156.055 & 156.20 & 156.244 & 156.28 & 156.269 \\
\hline $53^{\circ}$ & 156.03 & 156.035 & 156.20 & 156.216 & 156.18 & 156.171 \\
\hline$\sigma\left(\mathrm{kg} / \mathrm{mm}^{2}\right)$ & 135 & 13.7 & 05 & -15 & 15.6 & 193 \\
\hline$R$ & 0.9977 & 0.9826 & 0.3175 & $\begin{array}{ll}0 & 6282\end{array}$ & 09993 & 0.9963 \\
\hline Specimen & \multicolumn{3}{|c|}{$\mathrm{C}$} & \multicolumn{3}{|c|}{$\mathrm{D}$} \\
\hline$\Psi$ & \multicolumn{2}{|l|}{ A } & D & A & \multicolumn{2}{|r|}{ D } \\
\hline $11.59^{\circ}$ & 15658 & \multicolumn{2}{|c|}{156556} & 156.08 & \multicolumn{2}{|c|}{156075} \\
\hline $1159^{\circ}$ & 156.55 & \multicolumn{2}{|c|}{156.551} & 15605 & \multicolumn{2}{|c|}{156069} \\
\hline $2659^{\circ}$ & 156.56 & & 56.584 & 156.13 & & 56139 \\
\hline $41.59^{\circ}$ & 156.65 & & 56.638 & 156.18 & & 56.185 \\
\hline $5659^{\circ}$ & 156.73 & & 56.717 & 156.28 & & 56.312 \\
\hline $5659^{\circ}$ & 15673 & & 56719 & & & \\
\hline$\sigma\left(\mathrm{kg} / \mathrm{mm}^{2}\right)$ & -7.8 & & -7.6 & -94 & & 10.1 \\
\hline$R$ & 09735 & & 0.9955 & 0989 & & 0.9875 \\
\hline
\end{tabular}

よる測定は充分満足のいくものであったが，自動集録 の場合には, A-D変換器の直線性や変換速度なども 測定精度に影響を与えると考兄られるのでつぎにその 測定結果を報告する。

$4 \cdot 2 \cdot 2$ データ自動集録装置による測定結果 用 いた $\mathrm{A}-\mathrm{D}$ 変換器によって求められたディジタル測定 值が，自記したプロフィルと一致するかがまず問題と なるので，できるだけ回折線幅が狭く立ち上がりの急 なプロフィルルついて変換特性をチェックした．Fig. 7 はその結果の一例である.プロットしてある黒丸は 変換して得られた電圧に相当する. 原プロフィルと法 とんど同じ電圧が変換後にも得られている．ただよく 観察すると回折線の立ち上がりが大きい部分ではわず かではあるが，変換電圧の方が低い電圧であり，立ち 下がりの急な部分では逆に高くなっている．これは変 換器の時定数のために生じたものと考えられるが, 問 題とはならない程度のものと考光る。このデータで, アナログ法で求めたピーク位置は $156.375^{\circ}$ ，ディジタ ル法では $156.376^{\circ}$ であり前述のプロフィルより直接 求めたものと同様よい一致をみた。

ついで，材料 $\mathrm{A}, \mathrm{A}^{\prime}, \mathrm{B}$ 和よびCさらに他の材料に ついてアナログ法とディジタル法によってピーク測定 を行ない測定值の偏差を求め，78個のサンプルにつき 平均值を求めたところ，0.003であった。

さらに，試料 Cについては，既知の曲げ応力を与光 その際のX線応力をアナログ法とディジタル法の双方 で測定して比較を行なったが，その結果をFig. 8 に示 


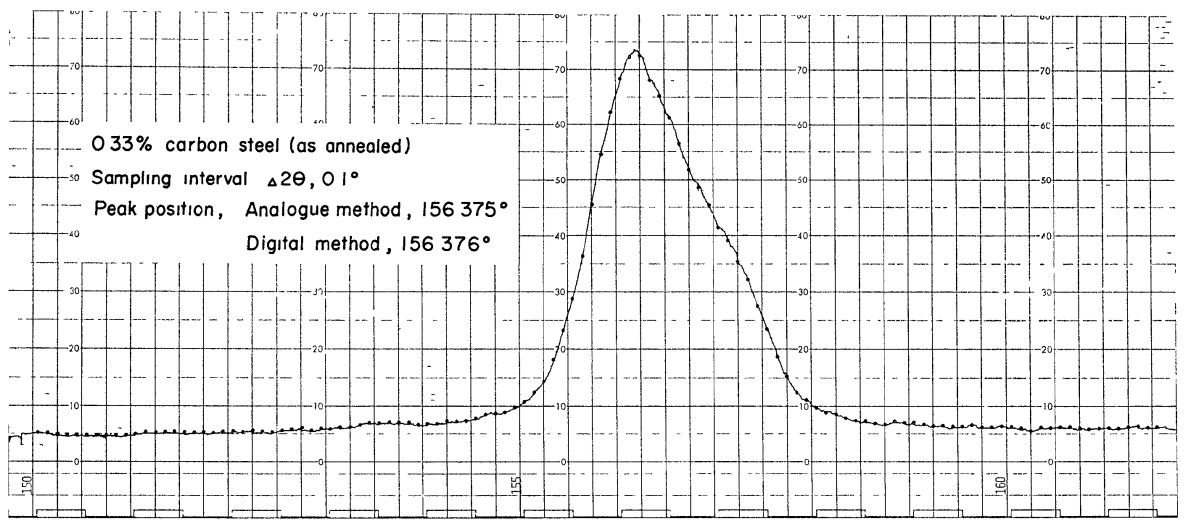

Fig 7. Plots of converted digital values of diffraction intensity to profile.

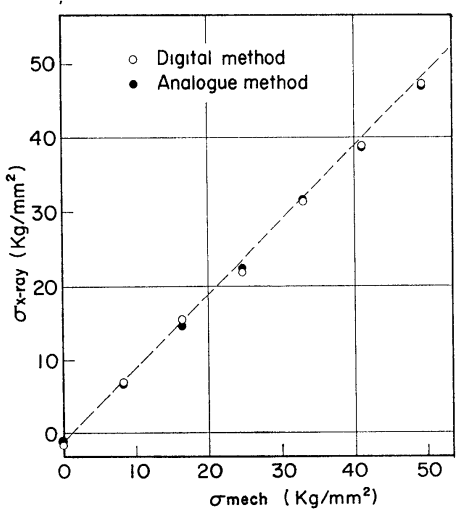

Fig. 8. Relation between applied stresses and X-ray stresses by analogue and digital methods. (Specimen C)

す.いずれの場合も応力測定值の差は $1 \mathrm{~kg} / \mathrm{mm}^{2}$ 以 内であり湘定誤差を考慮すればきわめて良い一致が得 られたものと考朰られよう。

\section{5 結 論}

X線応力測定を自動化する場合を考光, 半価幅法に よる回折線ピーク位置測定をディシタル計算で求める 方法を考光，従来の回折強度分布曲線上り図式に求め る方法と比較した。

その第一として，プロフィルより直接測定した回折 強度についてピーク位置を求め, さらにプロフィル信 号電圧をアナログーディジタル変換型電圧計で 自動的
に変換したものについても同様な測定を行なった。 測定結果はいずれの場合も図式に求めたものときわ めて良い一致が得られた。そうして応力值について子， $1 \mathrm{~kg} / \mathrm{mm}^{2}$ 以内の差に納まっていることが明らかにな った。この方法は, X線応力測定法標準で採用されて いる方法がそのま萿用できるため測定值の比較・検 討にも便利でまた回折線プロフィルも同時記録できる ため, 回折線プロフィル観察による材料の種々の情報 も同時飞得られる利点がある.

本報告では，測定法拉よび，データの自動集録によ る結果のみにとどまったが, X線入射角の設定, 計数 管の走査範囲の設定，運転を自動化して本装置と結合 すれば，試料セットが完了すればあとは測定結果まで が人手を経ず浣了させられよう。

さらに, 測定精度を非常に要求し, 吸収因子やかた より因子の補正などが必要となる場合にも，このよう なデータの集録方法は，その目的にかならものと考兄 る.

な朊, 計算は, 武蔵工業大学電子計算機 FACOM 270/30 そよった。

(昭和 48 年 8 月 22 日 第 1 回材料の力学的挙動飞関するシンボシウム にて講演)

考文 献

1）X線材料強度委員会，X線応力測定標準 (1973). 